薬学教育 6 年制の早期体験学習に関する 学生へのアンケート調査と炎の解析

平田千春 ${ }^{* 1}$, 中尾尚子 ${ }^{2}$, 柴田香織 ${ }^{1}$, 山本朋子 ${ }^{1}$, 沢崎高志 ${ }^{1}$, 長谷川 豊 $^{3}$, 蓮池賢一 ${ }^{3}$, 西田英之 ${ }^{4}$, 東 和夫 ${ }^{5}$, 金 啓二 ${ }^{6}$, 徳山尚吾 ${ }^{7}$, 福島昭二 ${ }^{7}$, 山岡由美子 ${ }^{7}$, 岩川精吾 ${ }^{8}$, 平井みどり ${ }^{9}$, 松山賢治 ${ }^{10}$, 内田享弘 ${ }^{11}$

神戶掖済会病院 ${ }^{1}$, イオン $(\text { 株 })^{2}$, 川崎病院 ${ }^{3}$, 石川島播磨重工業健保組合播磨病院 ${ }^{4}$

アズマ薬局 ${ }^{5}$, 神戶朝日病院 6 , 神戶学院大学薬学部 7 , 神戶薬科大学 ${ }^{8}$

神戶大学医学部附属病院薬斉部 9 , 共立薬科大学 ${ }^{10}$, 武庫川女子大学薬学部 11

\title{
Results of a Student Questionnaire on Experience of ' Early Exposure' Programme, the Initial-Stage of the 6-Year Pharmaceutical Educational Curriculum
}

\author{
Chiharu Hirata*1, Naoko Nakao ${ }^{2}$, Kaori Shibata ${ }^{1}$, Tomoko Yamamoto ${ }^{1}$, Takashi Sawasaki ${ }^{1}$, \\ Yutaka Hasegawa ${ }^{3}$, Kenichi Hasuike ${ }^{3}$ Hideyuki Nishida ${ }^{4}$, Kazuo Azuma ${ }^{5}$, Ke-lh Kim ${ }^{6}$, \\ Shogo Tokuyama ${ }^{7}$, Shoji Fukushima ${ }^{7}$, Yumiko Yamaoka ${ }^{7}$, Seigo Iwakawa ${ }^{8}$, Midori Hirai ${ }^{9}$, \\ Kenji Matsuyama ${ }^{10}$ and Takahiro Uchida ${ }^{11}$ \\ Kobe Ekisaikai Hospital ${ }^{1}$, Aeon ${ }^{2}$, Kawasaki Hospital ${ }^{3}$, Ishikawajima Harima Hospital ${ }^{4}$ \\ Azuma Pharmacy ${ }^{5}$, Kobe Asahi Hospital ${ }^{6}$ \\ Faculty of Pharmaceutical Sciences, Kobe-gakuin University ${ }^{7}$ \\ Kobe Pharmaceutical University 8 \\ Department of Hospital Pharmacy, School of Medicine, Kobe University ${ }^{9}$ \\ Kyoritsu University of Pharmacy ${ }^{10}$ \\ Faculty of Pharmaceutical Sciences, Mukogawa Women's University ${ }^{11}$
}

$\left[\begin{array}{l}\text { Received July 13, } 2007 \\ \text { A ccepted December 6, } 2007\end{array}\right]$

A questionnaire was given to students before and after the Early Exposure' programme, which was introduced in the first year of the 6-year pharmaceutical education course at the Faculties of Pharmaceutical Sciences at Kobe Gakuin University and Mukogawa Women's University, and Kobe Pharmaceutical University in Hyogo Prefecture. The objective of the questionnaire was to evaluate the success of the programme and a total of 847 students completed it. The major facilities participating in the programme were hospital and community pharmacies.

The major method of study was observation of the work of pharmacy facilities and it was used for more than $90 \%$ of the students. A bout 30\% studied through lectures and 25\% through actual work experience. Though almost half of the students learned about dispensing medication, fewer learned about medication history management and medication management.

We asked students to evaluate their educational experience using scores from 4 (good) to 1 (poor) and 2 major questions asked were whether the work of pharmacists was patient-oriented and whether they had good communication with other staff and patients. The students who observed the work of hospital or community pharmacies gave higher scores than those who did not and those who had actually experienced the work of pharmacies gave higher scores than those who had only observed their work or studied through lectures. The students were generally positive about the programme.

The Early Exposure programme seems to be appreciated by the participating students and we feel that maintaining close collaboration between community and hospital pharmacies and universities is important in achieving a high-quality educa tional syllabus for pharmacists. 
Key words — Early Exposure, collaboration among community pharmacy, hospital pharmacy and universities, 6-year pharmaceutical education, Kobe pharmacology network

\section{緒言}

医療の高度化と多樣化の中で, 薬学教育に対する社会 のニーズも非常に多樣化しており，臨床能力の高い薬剂 師の育成が社会から強く望まれている. 平成 18 年度よ り薬学教育 6 年制がスタートし, 日本薬学会が主体と なって作成した「薬学教育モデル・コアカリキュラ 厶」 ${ }^{12}$ の中に入学後早期に現場を体験するという早期体 験学習が加わった .この早期体験学習は, 薬学生の学習 に対するモチベーションを高め，医療人としての資質を 学びよりレベルの高い臨床薬剤師を育成していく上で非 常に重要である.しかし, 現在のところ大学側, 受け入 れ施設側ともに手探りで模索している状態である．今 後，早期体験学習をより良いものに改善するためにも， 学習を行う学生自身の意見を聞くことは必要不可欠であ る.これまで薬学生の実務実習に関してアンケート調査 や検討を行った報告は複数あるが ${ }^{3-9)}$, 早期体験学習に 関した複数の医療施設を対象としたアンケート調査の報 告は少ない .

乥こで今回 , 神戶薬学ネットワーク**の活動の一環 として, 兵庫県下の薬科大学・薬学部 3 大学に入学し初 めて早期体験学習を体験した薬学生を対象に，アンケー 卜調査を行い, 弚の結果について解析したので以下に報 告する$$
\text { アンケート対象 }
$$

平成 18 年 4 月に兵庫県下の大学に入学し, 早期体験 学習に参加した学生 847 名(神戶学院大学薬学部 282 名, 神戶薬科大学 343 名, 武庫川女子大学薬学部 222 名) を対象に行った．なお，3薬科大学の体験学習全体のプ ログラムは大学間で若干差があるものの, 学習前にガイ ダンスを実施し，教員の指導下で課題学習などを事前に 行った後，半日の体験学習を実施し，スモールグループ ディスカッション(SGD)，発表会，レポートなどでまと めるという全体の流れは同じである．実施時期は，入学 直後の 4 月から 7 月末であった .

\section{アンケート方法および解析結果}

1. アンケート回収率

早期体験学習前のアンケートの回収率は $98 \%$ であっ た . 早期体験学習後のアンケートの回収率は $96 \%$ で あった 。

\section{2. 早期体験学習前アンケート(図 1)}

1)薬学で使用される言葉の認知度調査(図 2)

薬学で使用される言葉の中で，「副作用」「処方せん」 「食間」は「知っている」が50\%を超えていたが，光の 他の言葉に関しては認知度が低かった . 知っていると答 えた学生でも「副作用」の意味を「身体に悪い効果」と 答えたり，「坐薬」を解熱剂と答えたりしており，正し く理解されていない可能性がある .

2)薬学部を選んだ理由

薬学部を選んだ理由は「資格が取れるから(590 名)」が 最も多く，ついで「医療関係に進みたいから(389名)」 「安定した職業だから(353名)」「薬剂師業務に興味があ るから(344名)」「人の役に立てると思ったから(339名)」 「親の勧めがあったから(256名)」「薬の研究に興味が あったから(235 名)」となっていた . (注 : 「トライやる・ ウィーク」とは, 兵庫県における公立中学校および県立 中等教育学校前期課程 2 年生の生徒全員を対象に行う体 験活動であり，さまざまな活動や体験を通して，豊かな 感性や創造性などを高めたり，自分なりの生き方を見つ けることができるように支援していく事業であり，「心 の教育」と位置付けられている .)

3)薬剤師業務に関する調査

学生の薬剂師業務に対する認識を調査したところ， 「調剂」を知っていると答えた学生が約 $60 \%$ と半数を超 えていた。しかし, 光れ以外の項目は「薬阂管理指導」 $27 \%$ ，「製剂」22\%，「学校薬剂師」20\%，「薬品管理」 19 $\%$ ，「治験」 $15 \%$ ，「薬歴管理」 $12 \%$ ，「注射薬調剂」10 \%となっており，すべて 30\% 以下の学生にしか認知さ れていなかった .

4)早期体験学習への心構え

早期体験学習で心がけることとして最も多かったのは 「質問をする(21\%)」であった．次いで「薬剤師(医療者) としての仕事内容を理解する(15\%)」「なるべく多くの 事を学ふぶ(7.6\%)」「挨拶をする(7.5\%)」となっている.

**薬学教員, 保険薬局, 病院, 診療所の薬剂師がお互いに連携を取りながら幅広く学習, 研究, 啓蒙活動を行い医療に貢献 することを目的として 1998年 7 月に設立.すでに 18 回にわたる講演会開催と, 学会発表数回, 論文揭載(医療薬学，2006 年1月号)を行っている. 


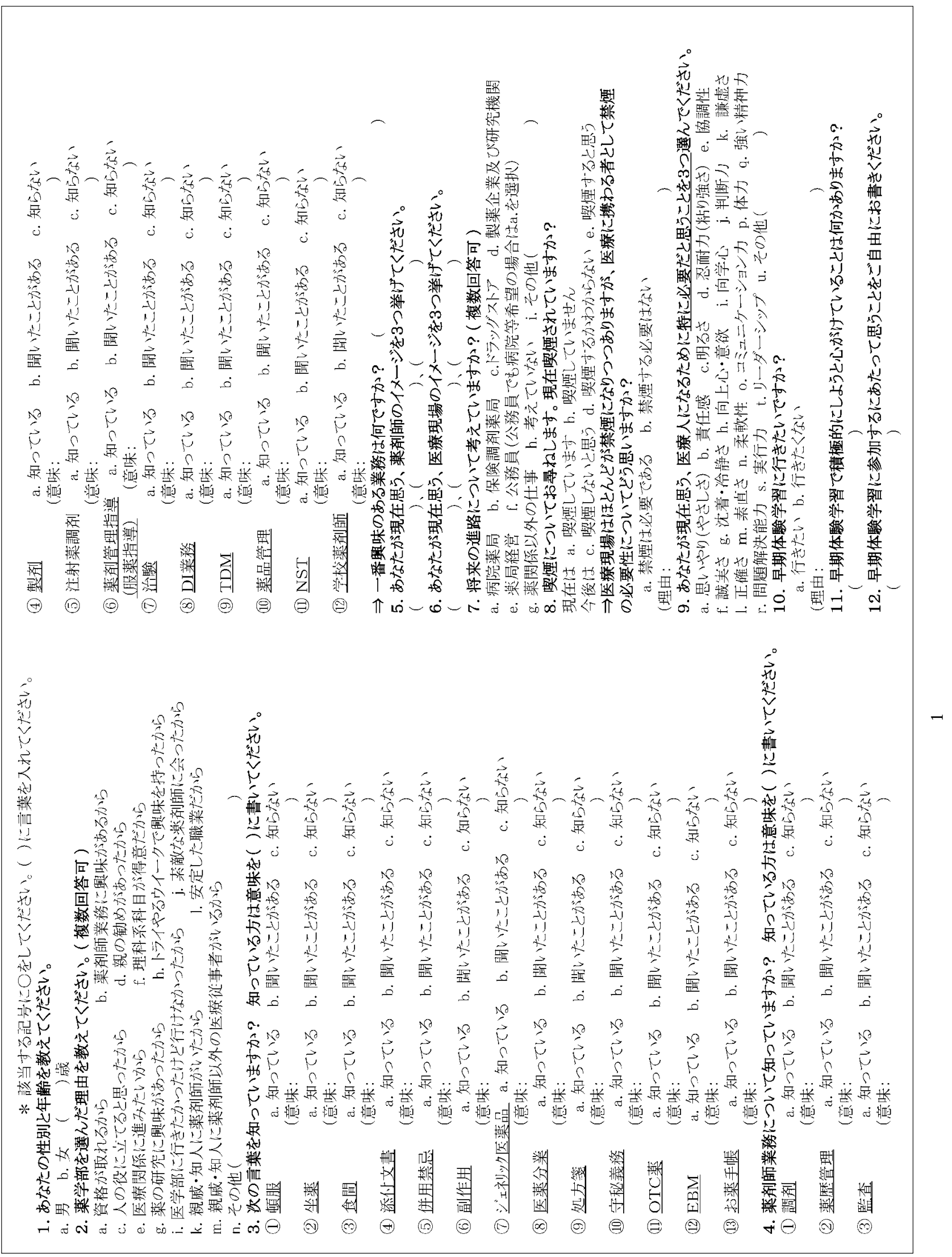




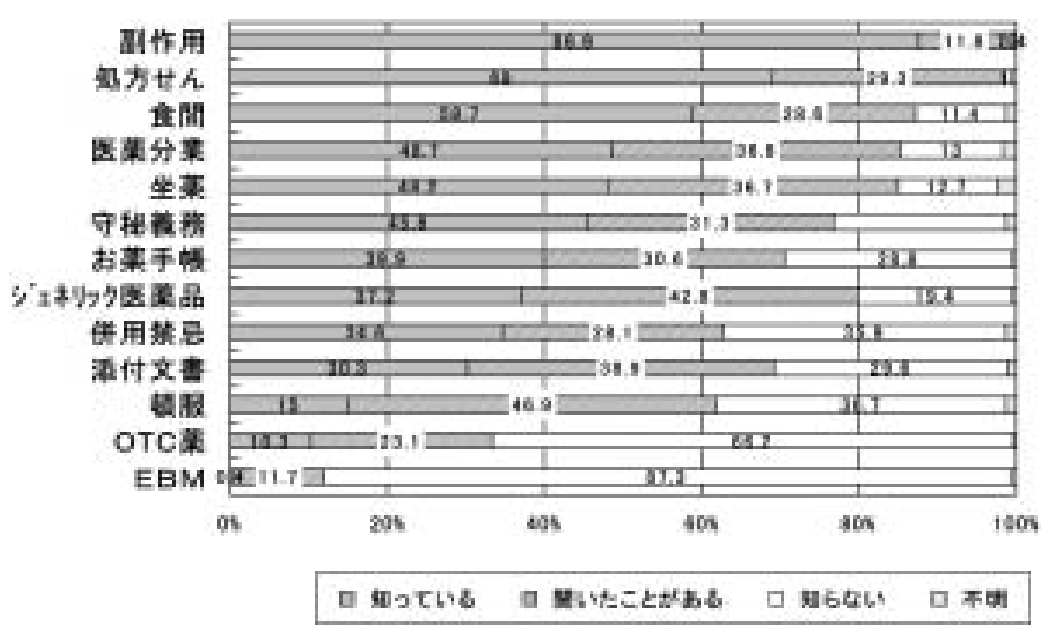

図 2 . 次の言葉を知っていますか

また 「話をよく聞く」「迷惑をかけないようにする」な ど，社会人であることを意識する意見もあった．

早期体験学習に参加するにあたって思うことでは， 「楽しみ, 嬉しい(16\%)」「がんばる $(9.9 \%) 」 な と ゙$ 前向きな 意見が多かったが「不安(9.2\%)」や「緊張する」といっ た意見もあった . また，早期体験学習に「行きたい」と 答えたのは 84.1\%，「行きたくない」と答えたのは $9.6 \%$ であった .

\section{3. 早期体験学習後アンケート(図 3)}

1)学習した施設

学習した施設を調査したところ，保険薬局(418人)と 病院(336人)が主であった . 兴の他には福祉施設や養護 学校, 血液センター, 卸物流センター等があった .

2)体験学習を終えての評価(図 4)

「時間・時期」については，時間は 2 3 時間を希望す る学生が $29 \%$ と最も多く，1２時間が 11\% であった . 日数は 1日が $47 \%$ で最も多く，2日間が $35 \% ， 3$ 日間 が 9\% であった . 長いと感じる評価 4 を選んだ学生は $17.5 \%$ ，評価 3，2，1は乥れ光れ $57.1 \% ， 22.1 \% ， 3.2 \%$

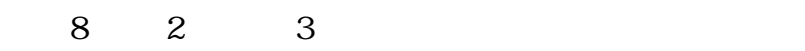
1年生のうちに行きたい」が $62 \%$ で最も多く，なかで も 4 6月が $27 \% ， 10 〜 12$ 月が $28 \%$ であった . また， 2 年生が $27 \%$ ，3年生が $8 \%$ であつた . 実施時期について 「適切である」の評価 4 を選んだ学生は $36 \% ， 3$ を選ん だ学生は $30 \%$ と，半数以上か評価 3 または 4 であった .

「体験した感想」施設での指導・説明」については， 体験した施設に関わりなく4段階評価で 3 または 4 の評 価をした学生は 8割以上であった。しかし，「薬剤師の 仕事の全体像」に関しては，4段階評価で3または 4 を 選んだ学生は,病院または保険薬局へ行った学生では 76 $\%$, 乥れ以外の施設のみの学生では $43 \%$ と半数以下と
なった 。

3)学習形式・学習内容について

学習形式は見学が 766 名, 講義 236 名, 体験 209 名と なっており，実際に何らかの体験をした学生は全体の 25 \%程度であった . 学習内容は「調剂」が 412 名で最も多 く約半数であった .ついで薬歴管理 266 名, 薬品管理 241 名,患者対応 177 名,製剂 174 名となっている .少なかっ たのは在宅医療 12 名，保険請求業務 16 名，TDM 21名， 治験 21 名であった。

印象に残っている体験としては施設や設備の見学(調 剂に用いる器具や機械類の説明・見学を含む), 調昘剖業 務，薬品管理などが多く挙げられていた．

一番興味を持った業務としても「調剂」業務が最も多 く，ついで「患者対応」「服薬指導」など患者と関わり のある業務が挙げられていた .

薬斉師の業務として想像していなかった業務として患 者との会話や服薬指導など患者と関わりのある業務が多 く挙げられていた、薬品管理や, 注射剂の混注業務, 無 菌室での操作など専門的業務も挙げられていた .

4)体験した現場について(図 5 , 図 6)

体験した現場についての質問において「患者中心の医 療であったか」「患者と薬剂師がコミュニケーションを 取れていたか」薬剤師の患者への対応」について，病 院または保険薬局へ行った学生(計 622名)では 3 または

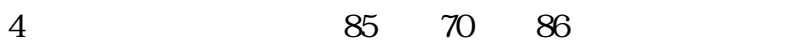
にも保険薬局にも行かなかった学生(計 187 名)では約 50 \%,25\%，47\%しかいなかった .

「スタッフが活き活きしていたか」については, 病院 または保険薬局へ行った学生では 3 または 4 の評価が $88 \%$, 光れ以外の学生では $78 \%$ と大きな差はないもの の，病院または保険薬局へ行った学生の方が高い評価を する傾向がみられた . 


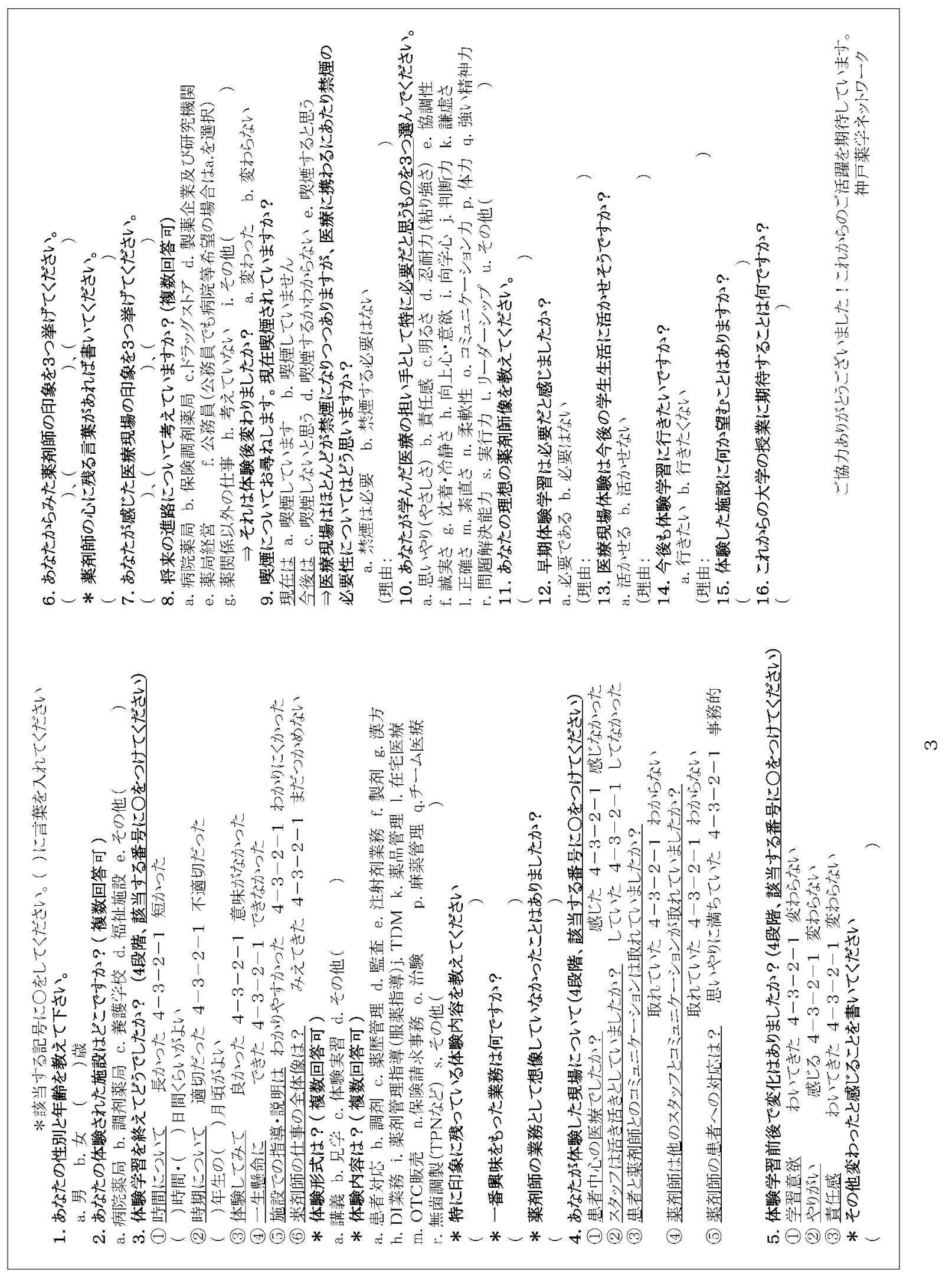


体験してみて

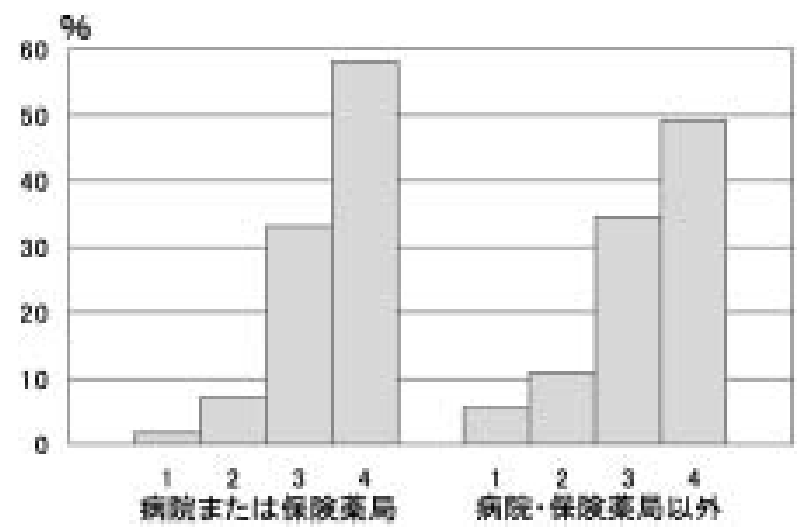

仕事の全体像は？

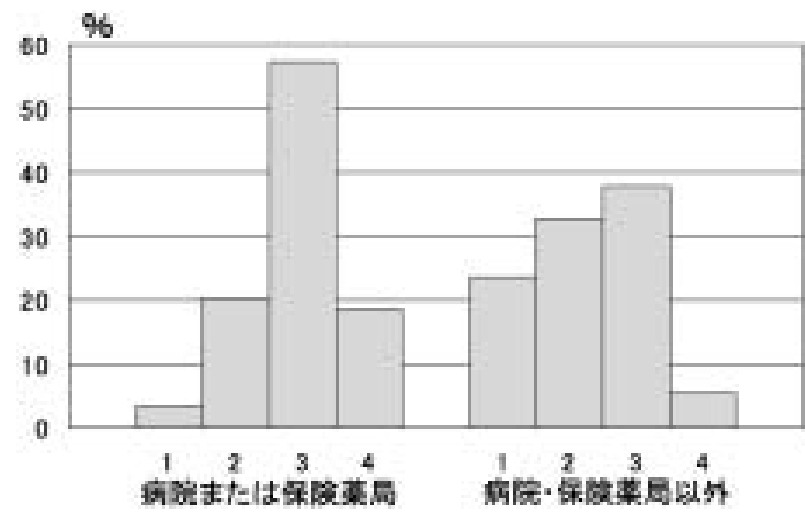

施設での説明は？

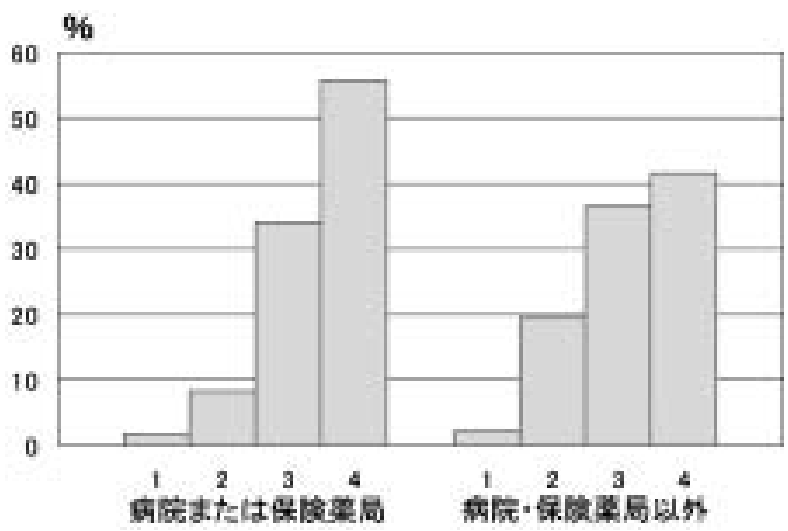

図 4. 体験を終えての評価

また，体験形式別ではどの設問においても，講義や見 学よりも体験をした学生の方が高い評価をする傾向に あった . 病院または保険薬局で学習した学生で体験形式 別に評価した場合, 見学講義のみよりも何らかの体験を した学生の方が， 3 または 4の評価をした学生の割合が やや高い傾向がみられた .

5)体験学習前後での変化について

$「$ 学習意欲」「やりがい」「責任感」については，「学習 意欲」「やりがい」はおよ光8割の学生が4段階評価で 3 または 4 の評価であった .「責任感」は約 9割の学生 が高い評価をした .

6)体験を終えて

体験学習を終えて，約 85\% の学生が早期体験学習は 「必要である」と感じたようだ．また，医療現場体験が 今後の学生生活に活かせるかどうかについては, 約 75 \%の学生が「活かせる」と答えた . 今後もまた行きたい かについては, 約 $75 \%$ の学生が「また行きたい」と答 えた。

必要ない理由としては「早すぎる」「薬剂師と関係の ないところへ行っても仕方ない」「希望のところへ行け ない」などがあった．今後行きたくないと答えた学生は，
理由として「薬学と関係のあるところへ行きたい」「1 回で十分」「つまらない，めんどう」「見学だけなら必要 ない」などを挙げている .

\section{7)理想の薬剤師像}

理想の薬剂師像を尋ねたところ患者から信頼されてい る人が $14 \%$ ，次いで患者のことを(一番に)考えられる人 が $7.4 \%$ ，コミュニケーションが取れるが $6.2 \%$ ，思いや りがある人が $4.9 \%$, 責任感がある人が $4.0 \%$ であった .

8)大学・施設に対して

体験した施設に望むこととして多かったのは「何かを 体験したい $(32 \%) 」 「$ 薬剂師の仕事をもつと教えてほし

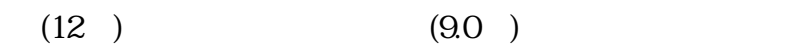
輩に同じように体験させてあげてほしい」「またこのよ うな体験をさせてほしい」といった前向きな意見もあっ たが, 逆に「講義ばかりであるとつらい」「専門用語が わかりにくい」「質問する時間を増やしてほしい」など の意見もあった .

大学の授業に望むこととして，「わかりやすい授業(11 \%)」「体験を増やしてほしい(9.1\%)」「薬剂師に必要なこ と(実践的なこと)を教えてほしい(6.9\%)」などが多かっ た. 


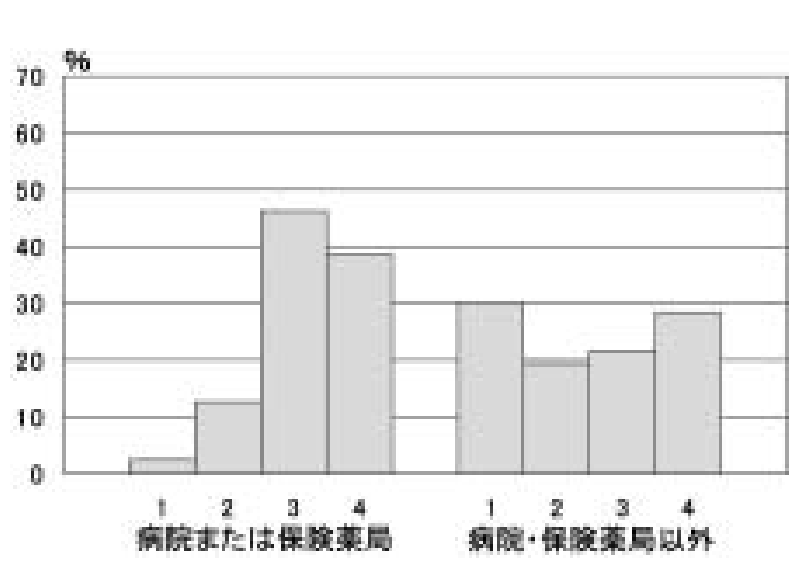

患者と薬剂師のコミュニケーションは取れていましたか？

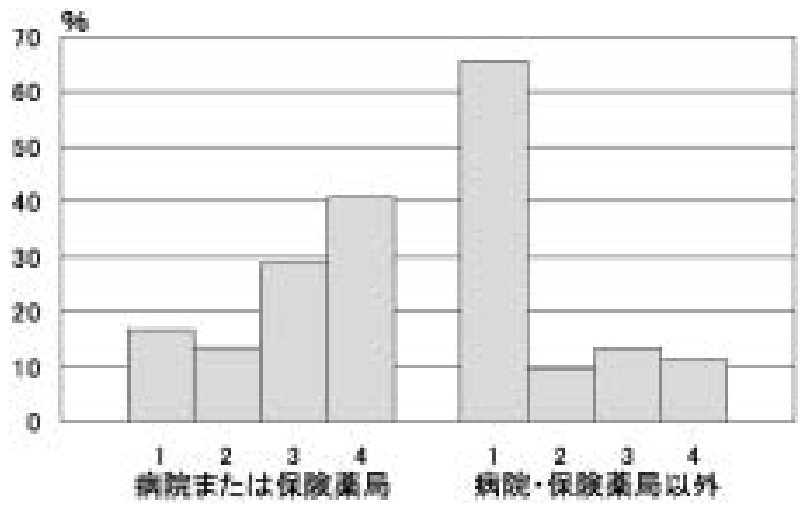

スタッフは活き活きしていましたか？

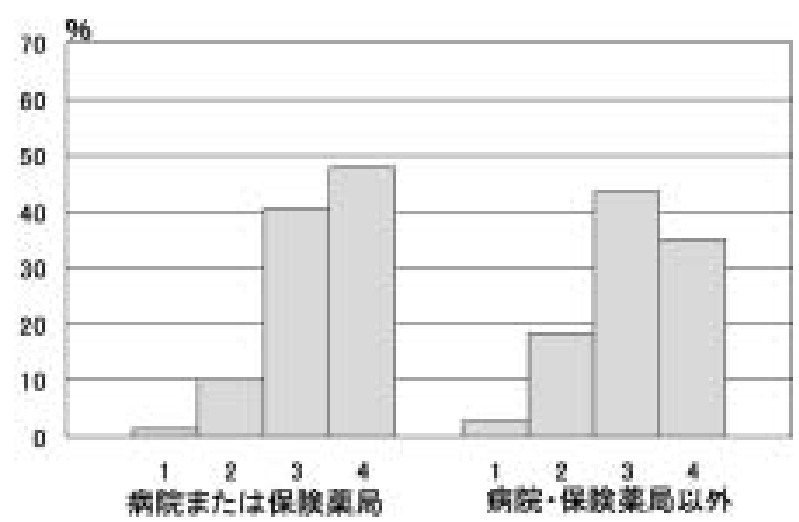

薬剂師の患者への対応は？

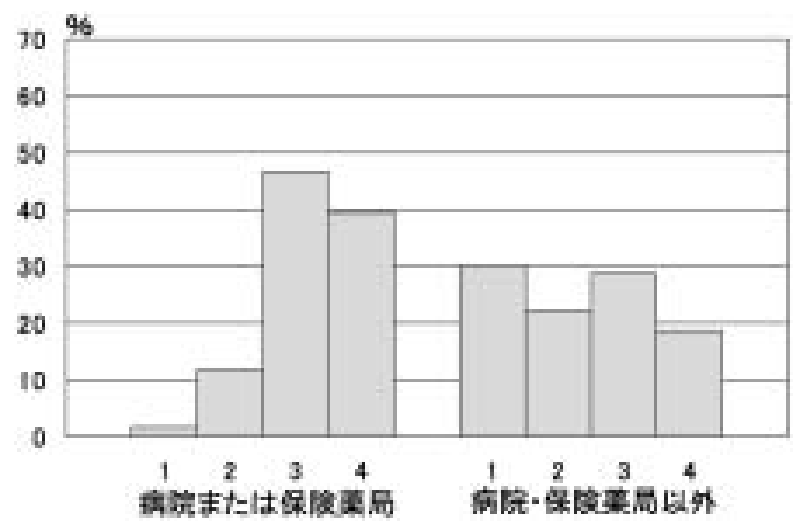

図 5 . 体験した現場についてー体験施設別に一

4. 早期体験学習前後共通アンケート

1)薬剂師のイメージ(図 7)

薬剂師のイメージは, 早期体験前後ともに「責任感が ある」が1位であったが，体験後には体験前に比べて 2 倍以上の学生が答えていた．体験前には 10 位以内に入っ ていなかったが，「思いやり」「コミュニケーション」 「真面目」「正確」「判断力がある」といった意見がみら れる一方で「大変」という意見も寄せられた．

2)医療現場のイメージ

医療現場のイメージは, 早期体験前後ともに「忙し い」「責任」「清潔」大変」などの言葉が多かった .

3)将来の進路

将来の進路は, 早期体験前は「病院薬斉師(70\%)」「製 薬企業および研究機関(37\%)」「保険薬局(28\%)」であっ た．体験後は「病院薬剂師(62\%)」「保険薬局(34\%)」「製 薬企業および研究機関(33\%)」であり，体験前後で同樣 の傾向がみられた . また，早期体験前後で「変わった」 が12\%，「変わらない」が75\%であった .

4)医療の担い手について

医療の担い手として特に必要だと感じるものとして， 早期体験前後ともに「責任感」と答えた学生が約 70\%
と最も多く，ついで「思いやり(やさしさ)(約 50\%)」「コ ミュニケーション力(約 40\%)」であった .

5)喫煙について

医療施設の禁煙化が進む中，医療従者としての自覚を 持つことができたかどうかを，喫煙に対する考え方より 考察するため，喫煙に関するアンケートを行った . 現在 の喫煙率は，体験前後ともに約 $2 \%$ であった . 今後喫煙 するかどうかについては「喫煙しないと思う」が体験前

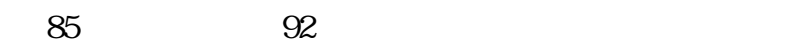
う」が体験前後ともに約 7\%であった .

また, 禁煙の必要性については,「必要である」と答

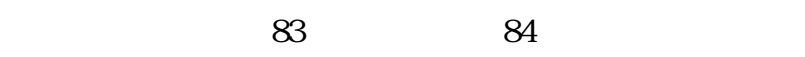
答えたのは体験前は $10 \%$ ，体験後は $14 \%$ であり，体験 前後で同程度であった . 理由に関しても，体験前後とも に「医療従事者だから禁煙は必要だ」と答えた学生が多 く，ついで「体に悪いから」となっている，体験の有無 に関わらず医療従事者として禁煙は必要と考える学生が 多いことがうかがえた . 
患者中心の医療でしたか？

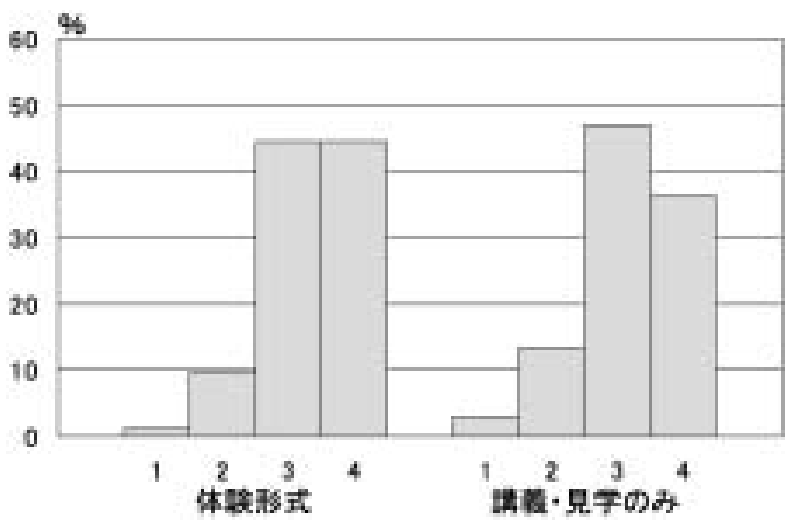

患者と薬斉師のコミュニケーションは取れていましたか?

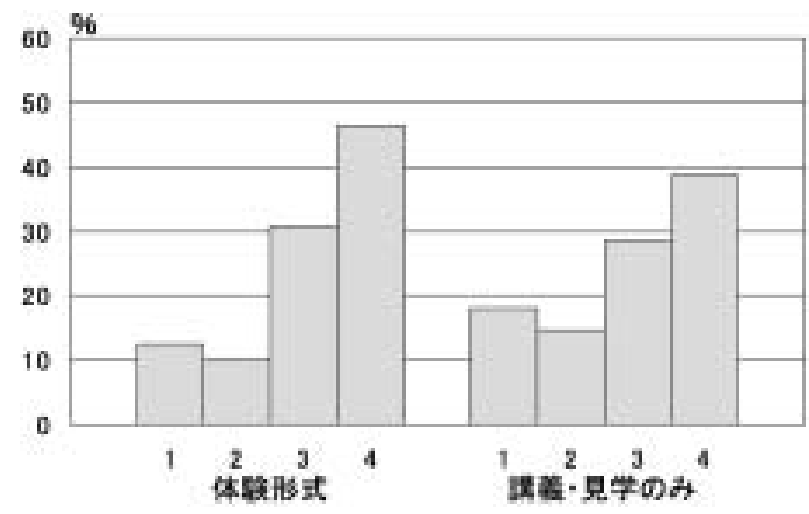

スタッフは活き活きしていましたか？

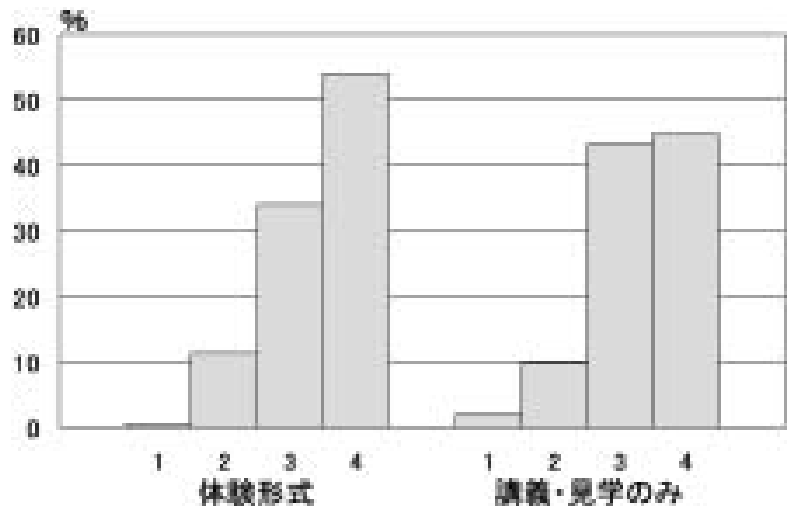

薬斉師の患者への対応は？

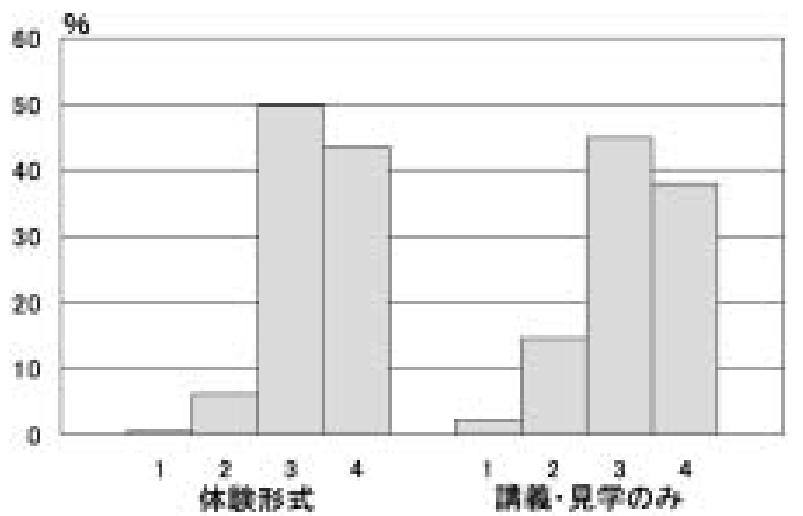

図 6 . 体験した現場について - 体験形式別に-

\begin{tabular}{|r|l|r|}
\hline \multicolumn{3}{|c|}{ 体 験 前 } \\
\hline 1位 & 責任感がある & $\mathbf{1 7 . 8 \%}$ \\
\hline 2位 & 賢い & $\mathbf{1 6 . 3 \%}$ \\
\hline 3位 & 優しい & $\mathbf{1 1 . 1 \%}$ \\
\hline 4位 & 清潔 & $10.5 \%$ \\
\hline 5位 & 知識が豊富 & $9.6 \%$ \\
\hline 6位 & 安定 & $7.7 \%$ \\
\hline 7位 & 白衣 & $7.1 \%$ \\
\hline 8位 & 高収入 & $6.9 \%$ \\
\hline 9位 & 親切 & $6.7 \%$ \\
\hline 10位 & 信頼 & $6.5 \%$ \\
\hline
\end{tabular}

\begin{tabular}{|r|l|r|}
\hline \multicolumn{3}{|c|}{ 体 験 前 } \\
\hline 1位 & 責任感がある & $\mathbf{3 6 . 0} \%$ \\
\hline 2位 & 優しい & $\mathbf{1 1 . 4 \%}$ \\
\hline 3位 & 思いやり & $\mathbf{1 0 . 3 \%}$ \\
\hline 4位 & コミュニケーション & $7.9 \%$ \\
\hline 5位 & 真面目 & $7.2 \%$ \\
\hline 6位 & 正確 & $6.8 \%$ \\
\hline 7位 & 信頼 & $6.4 \%$ \\
\hline 8位 & 大変 & $5.9 \%$ \\
\hline 9位 & 親切 & $5.8 \%$ \\
\hline 10位 & 判断カがある & $5.7 \%$ \\
\hline
\end{tabular}

図 7 . 薬斉師のイメージ

考察

今回のアンケート調査の結果 , 多くの学生が体験は有 意義であったと感じ，前向きな理想の薬剂師像を持つこ とができたことがわかった．しかしながら，有意義でな
かったと感じる学生も存在し, モチベーションの向上を 目的とした学習であるため, 学生の意見をどのように取 り入れるべきかなどか課題である. 以下に学習形式・内 容について考察した . 
1. 学習形式について

実習時間は，2～3時間を希望する学生が 51\% と半数 を占め, 日数も 1 日間を希望する学生が $47 \%$ とこちら も半数近かった．4段階評価では，長いと感じる4 4 短 いと感じる 1 との間である 2 と 3 を選んだ学生が約 8 割 であり，多くの学生にとって適切な時間だったと思われ る.しかし，実際の体験学習時間については 3〜4時間 が $29 \%$, 日数については 2 日間が $35 \%$ となっている . 体験した施設に望むこととして「もっと長く見学した かった」「質問の時間を増やしてほしい」といった意見 もあり, 意欲的な学生にとっては短かったのではないか と思われる .

実習実施の時期は , アンケート結果では 1年生に行き たいと答えた学生が $62 \% ， 2$ 年生が $27 \%$ であった . 1 年生の中でも 4〜 6月は 27\%，10１2月が 25\% となっ ており，1年生の4〜6月よりも遅い時期を希望する学 生の方が多かった . 知識がないうちに実習に行っても意 味がないという意見や，実習に行くのに不安を感じてい る学生もいたようである.今回の早期体験学習は, 知識 を生かしたり技術を習得したりすることではなく，実際 に医療現場を見ることにより医療の担い手としての自覚 を持ち学習意欲を高めることである．目的を理解してい ない学生は無意味に感じたかもしれない．より意義のあ る体験学習にするためには大学で事前に学習目的を明確 にしておくことが必要であろう.

体験施設は大学によりさまざまであった．「患者中心 の医療であったかどうか」患者と薬剂師がコミュニ ケーションを取れていたかどうか」「他のスタッフと薬 剂師とのコミュニケーションが取れていたかどうか」 $\ulcorner$ 患者への対応」のどの設問においても，病院もしくは 保険薬局へ行った学生(622名)では，4段階評価におい て評価が高く，どちらにも行かなかった学生(187 名)で は評価が低かった . 早期体験学習の目的が医療の担い手 としての自覚を持つことであるならば，患者との関わり を理解すべきである . 产のためには患者のいる施設であ る病院や保険薬局での学習の方が適しているといえる . また，「薬剂師の仕事の全体像が見えてきたか」につい ては, 病院もしくは保険薬局へ行った学生では 4段階評 価で3または 4 の評価をしたのは全体の $75 \%$ であった が，どちらにも行かなかった学生では $43 \%$ とかなり低 かった . 早期体験学習の一般目標として卒業生の活躍す る現場などを体験することが挙げられている．多くの薬 剂師は病院もしくは保険薬局で働くことになり，光れ以 外の施設で働く薬斉師の方が少ないであろう . 病院また は保険薬局以外の施設で働く薬斉師の仕事のみを体験す るのは, 薬剤師の仕事の一部のみの体験であり, 薬剂師 の仕事内容をある程度理解するにはやはり病院もしくは 保険薬局での学習が必要であろう. 病院・保険薬局で
は, 患者が存在することにより患者との関わりを学ぶこ とができる . 病院・保険薬局以外の施設としては, 福祉 施設や養護学校, 血液センター, 卸物流センターなどが あったが，これらの施設には薬剂師が存在していない場 合もある . 血液センターや卸物流センターなどは広い意 味では医療の担い手といえるが，患者との関わりがわか りにくい．医療の担い手としての自覚を持たせるために は光れらの施設が医療現場あるいは患者とどのように関 わっているかを理解する必要があるだろう.いずれにし ても病院または保険薬局などの患者が存在する医療現場 を見た上で，产の他の施設は光れらの医療現場を取り巻 く環境として医療現場との関わりを理解していくのが理 想ではないかと考える. 今後 , 多くの学生に , 病院また は保険薬局を含めた多くの施設を見学させることが体験 学習の趣旨からも望ましく，大学側が施設確保の点で一 層努力する必要がある . また，各施設の種々の体験をス モールグループディスカッション(SGD)や発表会を通じ て, 学生全員に共有させることが重要であろう.

\section{2. 学習内容について}

学習内容を形式別にみたところ，見学学習が 766 名と 全体の約 95\% を占めた . 講義形式であった学生が 29 $\%$, 実際に何かを体験した学生は $25 \%$ 程度であった(複 数回答可). 大学入学後間もない時期であり，専門知識 のない状態での学習において実際に学生に何かを体験さ せるというのは難しいと思われる．しかし，「患者と薬 剂師のコミュニケーションが取れていたか」「患者中心 の医療であったか」「スタッフが活き活きとしていた か」「患者への対応」について 病院または保険薬局へ行っ た学生の場合，見学や講義のみより体験を取り入れた方 が評価の高い学生が多い傾向にあった . 大きな差はな かったものの，体験の内容によっては医療現場や薬剂師 についてより理解を深めることができる可能性はあるだ ろう.

学習内容で最も多かったのは調剂業務であった . 体験 学習後に学生が一番興味を持った業務もやはり調剂業務 が多かった．調斉業務は，病院もしくは保険薬局であれ ばどの施設でも行われている業務であり学生の認知度も 高く，体験学習として取り入れやすいものである．薬の 専門家であることが実感でき，また調剂した薬は患者の 手に渡り，患者の役に立っているという実感を持つこと ができる．患者と関わることで医療者としての実感や自 覚を持てるのではないだろうか．「患者との関わり」は 興味を持った業務にも挙げられている . 学生にとっても 関心の高い内容であり，また薬剂師の役割を理解しやす く, 今回の学習の目的達成に大きく貢献した内容と思わ れる .

また，「薬歴管理」「薬品管理」「製剂」などの業務は専 
門性を活かした業務といえる．学生が興味を持った業務 としても薬品管理, 血液センターでの血球分離や輸血製 斉の管理，注射剂の混注や無菌調製などが挙がってお り，これらの専門的業務について学生の関心は高いよう であった . 大学での授業で習得する知識や技術は，これ ら専門的業務に必要なものである. 今後, 大学で習得し ていくものが医療現場で必要であることを理解できれ ば，学習意欲を高めることができるのではないだろう か. これら専門的業務についての学習も今後多く取り入 れていくべきだと考える .

\section{3. まとめ}

今回の結果, 多くの学生が体験は有意義であつたと感 じていることがわかったが, 受け入れ施設や学習内容は さまざまであり，有意義でなかったとアンケートで回答 した学生も存在した．しかしながら，さまざまな施設で 薬斉師が活躍していること，また产の業務内容について 学んだようである.これらの内容を学生が大学に持ち帰 り，乥れ奖れが学んだことを話し合い体験や知識を共有 することにより薬阂師について理解を深めることができ るのではないだろうか . 体験学習後, 薬剤師のイメージ では「責任感」「思いやり」「コミュニケーション」が挙 げられ，理想の薬㓢師像としては「患者から信頼される 人」患者のことを考えられる人」「コミュニケーション が取れる」などが挙げられ，薬阂師は知識や技術だけで なく患者がいてこ关意義のある存在であることが学生に も伝わっている .これらのことを学生同士でも共有して ほしいものである .

薬学教育 6 年制が始まり，より臨床能力の高い薬剤師 が求められている．今回の体験学習で臨床現場であるべ き薬剂師の姿はおおむね学生に理解されたと思われる . 早期にこのような体験をすることは非常に重要であり， 医療人としての資質を育むよい機会といえる .この機会 をより充実したものにするためにも，薬一薬一学連携を いっ光う強化し充実させていくことが必要であり，臨床 能力の高い薬剂師養成に重要であると思われる。
謝辞 本研究にあたり，アンケート調査に協力していただ いた大学の関係者の方に深謝いたします．

\section{引用文献}

1) 日本薬学会, 薬学教育モデル・コアカリキュラム, 薬学教育実務実習・卒業実習カリキュラム，2002 年 8 月。

2) 市川厚, 薬学教育モデル・コアカリキュラムがめざ すもの, 月刊薬事 , 45, 1603-1608 (2003).

3）尾鳥勝也, 白井裕二, 三尾良一, 岩田正則, 森田雅 之, 酒井英洋, 矢後和夫, 全田浩, 薬斉師養成教育 改革に伴う長期実務実習への対応，「グループ病院 実習制度の」モデル事業の試み，医療薬学，30,103 112 (2004).

4) 南砂, 社会が求める薬阁師の姿, 月刊薬事 , 47, 1923 (2005).

5）望月正隆, 新たな薬学教育は国民に何を約束する か, 月刊薬事 , 47, 15-18 (2005).

6) 太田由美, 成橋和正, 西尾千草, 太田英夫, 南奈津 子, 清水栄, 鈴木永雄, 中田勝, 中規模病院におけ る薬学部生病院実習カリキュラム作成, 医療薬学, 29, 129-139 (2003).

7) 中村誓志, 中村暢彦, 佐藤昌美, 吉田由香理, 三石 哲也，籠本基成，高田成子，藤田清，杉山正敏，二 見高弘, 薬学部病院実務実習生を対象とした理解度 調査により浮かび上がった問題点, 医療薬学, $\mathbf{3 0}$, 672-678 (2004).

8）細見光一, 室井延之, 東和夫, 池田りき子, 魚本智 子, 大川恭子，三宅圭一, 中川素子, 河本由紀子， 清原義史，金啓二，沢崎高志，小野達也，西田英之， 大野真理子，緒方園子，福島昭二，德山尚吾，大西 憲明，平井みどり，松山賢治，保険薬局および病院・ 診療所のおける学生実務実習の実態調査, 医療薬 学, 32, 64-72 (2006).

9）寺町ひとみ，高島英滋，窪田傑文，土屋照雄，病院 および薬局実務実習における学生および指導薬阁師 による評価，医療薬学，32, 997-1008 (2006). 